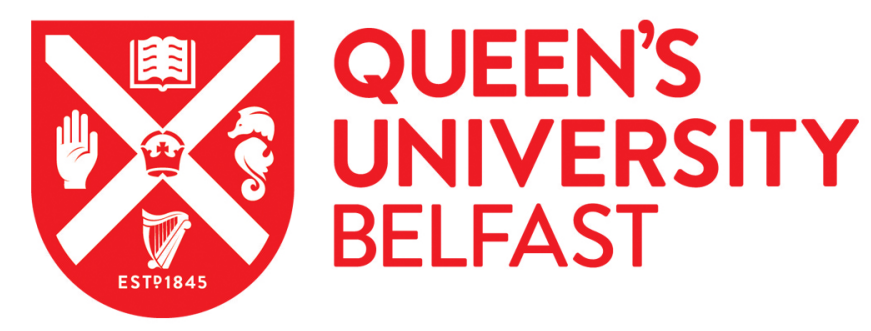

\title{
Synthesis of nucleoside phosphoroselenolates via the efficient Michaelis-Arbuzov reaction of selenocyanates
}

Eguaogie, O., Conlon, P. F., \& Vyle, J. S. (2016). Synthesis of nucleoside phosphoroselenolates via the efficient Michaelis-Arbuzov reaction of selenocyanates. Tetrahedron Letters, 57(45), 5000-5002.

https://doi.org/10.1016/j.tetlet.2016.09.096

\section{Published in:}

Tetrahedron Letters

Document Version:

Peer reviewed version

Queen's University Belfast - Research Portal:

Link to publication record in Queen's University Belfast Research Portal

Publisher rights

(c) 2016 Elsevier Ltd. This manuscript version is made available under the CC-BY-NC-ND 4.0 license http://creativecommons.org/licenses/by$\mathrm{nc}-\mathrm{nd} / 4.0 /$,which permits distribution and reproduction for non-commercial purposes, provided the author and source are cited.

\section{General rights}

Copyright for the publications made accessible via the Queen's University Belfast Research Portal is retained by the author(s) and / or other copyright owners and it is a condition of accessing these publications that users recognise and abide by the legal requirements associated with these rights.

Take down policy

The Research Portal is Queen's institutional repository that provides access to Queen's research output. Every effort has been made to ensure that content in the Research Portal does not infringe any person's rights, or applicable UK laws. If you discover content in the Research Portal that you believe breaches copyright or violates any law, please contact openaccess@qub.ac.uk. 


\title{
Synthesis of nucleoside phosphoroselenolates via the efficient Michaelis- Arbuzov reaction of selenocyanates
}

\author{
Olga Eguaogie, Patrick F. Conlon, and Joseph S. Vyle ${ }^{\mathrm{a}}$. \\ School of Chemistry and Chemical Engineering, Queen’s University Belfast, David Keir \\ Building, Stranmillis Road, Belfast BT9 5AG, UK
}

\begin{abstract}
The Michaelis-Arbuzov reactions of benzylselenocyanate and 5'deoxythymidine-5'-selenocyanate with thymidine $H$-phosphonate proceeded rapidly in the presence of a neutral silylating agent and 2,6-lutidine to give the corresponding Se-alkyl phosphoroselenolate triesters. Deprotection under mild conditions enabled the isolation of phosphoroselenolate diesters which were fully characterised.
\end{abstract}

KEYWORDS: Michaelis-Arbuzov; Phosphoroselenolate; Nucleotide; Selenocyanate.

Selenium-substituted nucleoside and nucleotide analogues are well-established, ${ }^{1,2}$ and their utility as antiviral ${ }^{3}$ or antimicrobial agents, ${ }^{4}$ in DNA labeling, mechanistic studies and in structural biology ${ }^{5,6}$ has led to considerable interest in novel methods for their efficient synthesis. Typically, such analogues involve chalcogen substitution of the nucleobase ${ }^{7,8}$ or sugar $^{9-11}$ moieties. Less frequently, selenium has been introduced within an internucleotide phosphate diester moiety as a replacement for either a non-bridging ${ }^{12-14}$ or a $5^{\prime}$-bridging ${ }^{15}$ oxygen atom. In the former case, the resultant phosphoroselenoates were sufficiently stable to enable multi-wavelength anomalous dispersion phasing, however, the diastereomers were found to degrade upon storage. ${ }^{13}$ To the best of our knowledge, only a single description of the preparation of an internucleoside phosphoroselenolate linkage has been published following bromide displacement by a phosphoroselenoate diester. ${ }^{15}$ However, characterisation of the material (and subsequent deprotection products) relied solely upon mass spectrum and ${ }^{31} \mathrm{P}$ NMR data (vide infra).

Sekine and Hata also described an efficient Se-alkylation following in situ hydrolysis of a per-silylated nucleoside phosphoroselenoate monoester in the presence of ethyl bromide. ${ }^{16}$ In the same communication, these authors described a near quantitative Michaelis-Arbuzov (MA) reaction of a nucleoside 5'-bis(trimethylsilyl)phosphite with diphenyl diselenide, but hydrolytic desilylation to the corresponding Se-phenyl phosphoroselenolate diester was accompanied by P-SeAr bond scission. However, M-A chemistry is not supported by dialkyl (as opposed to diaryl) diselenides and to address this issue, Yan and co-workers recently described the application of Se-(2-cyanoethyl)phthalimide to the efficient preparation of an internucleoside phosphoroselenolate triester. ${ }^{17}$

Despite the greater accessibility of alkyl selenocyanates ${ }^{18}$ compared with selenophthalimides and the demonstrated reactivity of the SeCN functionality with low oxidation state phosphorus nucleophiles, ${ }^{19-22}$ the M-A reactions of nucleoside selenocyanate substrates have not, to the best of our knowledge been reported previously. Herein, we demonstrate the high efficiency of such chemistry under solution-phase conditions and its application to the synthesis of the first, fully-characterised, internucleoside phosphoroselenolate linkage.

The nucleoside $H$-phosphonate monoester substrate for the M-A reaction (1, Scheme 1 ) was readily prepared by hydrolysis of the corresponding phosphoramidite in the presence of a 
mild activator (5-(ethylthio)-1H-tetrazole) under literature conditions. ${ }^{23}$ Selenocyanates (2a, 2b) were prepared in a ball mill. ${ }^{24}$ Previously, M-A reactions using substrates such as $\mathbf{1}$ have been performed using a two-step procedure: ${ }^{23,25} \mathrm{H}$-phosphonate diester silylation / activation followed by M-A reaction with a chalcogen electrophile. However, in the presence of a large excess (typically 14 equiv) of the neutral silylating agent $\mathrm{N}, \mathrm{O}$-bis(trimethylsilyl)acetamide (BTMSA), we observed $c a$. $25 \%$ of a ${ }^{31} \mathrm{P}$ NMR signal $\left(\delta_{\mathrm{P}} \sim 120\right)$ associated with the bissilylated (decyanoethylated) phosphite (prepared independently from the corresponding 3'$H$-phosphonate monoester). Although this side-product reacted with high efficiency to give the corresponding silylated phosphoroselenolate diester, subsequent deprotection and isolation of pure products was complicated by rapid detritylation of the anionic diester during hydrolytic removal of the TMS functional group. In contrast, negligible levels of the decyanoethylated products were observed in the ${ }^{31} \mathrm{P}$ NMR spectrum of the reaction mixture using two equivalents of BTMSA and a mild base in the presence of benzylselenocyanate. Under such conditions, 99\% consumption of $1\left(\delta_{\mathrm{P}} 6.7\right)$ was found within 30 minutes (Figure 1).

No downfield resonances associated with P(III) intermediates were observed and ca. $90 \%$ of the product peaks were associated with the diastereoisomeric phosphoroselenolate triester 3a $(\delta \mathrm{P} 20.72$ and 20.87$)$ accompanied by satellite peaks due to coupling with ${ }^{77} \mathrm{Se}\left({ }^{1} \mathrm{JPSe}_{\mathrm{PS}}=524\right.$ $\mathrm{Hz})$.

The crude product could be isolated essentially free from contaminating phosphoruscontaining materials following extraction and precipitation from hexane. In our hands, removal of both cyanoethyl and trityl protecting functional groups required rapid isolation in order to achieve clean products by ${ }^{31} \mathrm{P}$ NMR. Thus, volatile base and acid reagents were used to unmask the phosphate diester and 5'-hydroxyl moieties respectively. Specifically, upon treatment with $10 \% t$-butylamine in pyridine, ${ }^{26}$ decyanoethylation of 3a was complete within 30 minutes at room temperature and the phosphoroselenolate diester was isolated following precipitation. ${ }^{31} \mathrm{P}$ NMR analysis showed a single product peak at $\delta_{\mathrm{P}} 11.16$ with the expected satellite peaks associated with ${ }^{77} \mathrm{Se}$ coupling $\left({ }^{1} J_{\mathrm{PSe}}=400 \mathrm{~Hz}\right)$. As found during the M-A reaction, storage as a solution in the absence of base resulted in detritylation as indicated by the emergence of further peaks downfield shifted by $c a .0 .1 \mathrm{ppm}$. Isolation of the fully detritylated product (4a) was expedited using chemistry developed for the deprotection of boranophosphates: ${ }^{27}$ treatment of a solution of the precipitated phosphoroselenolate diester with $1 \%(\mathrm{v} / \mathrm{v})$ trifluoroacetic acid in the presence of the carbenium ion scavenger triethylsilane gave complete detritylation within ten minutes (by TLC). Subsequently, crystallisation was observed although a considerable fraction of the product also remained in solution and therefore pure $\mathbf{4 a}$ was isolated as a hygroscopic salt (with a mixture of pyridinium and $t$-butylammonium counter ions) by precipitation. The poor recovery (39\%) reflected the surprising solubility of $\mathbf{4 a}$ in the precipitating solvents (hexane / ether).

We subsequently applied this chemistry to the preparation of the internucleoside phosphoroselenolate linkage with only minor modification. In order to maintain the nucleoside 5 '-selenocyanate (2b) in solution, persilylation of this compound required a larger excess of BTMSA (5.0 equiv). Essentially complete consumption of $\mathbf{1}$ was again observed within 30 minutes in the presence of 2,6-lutidine and the phosphoroselenolate triester (3b) isolated by precipitation. Deprotection of $\mathbf{3 b}$ yielded the corresponding detritylated diester TpSedT (4b) as a hygroscopic salt in $58 \%$ yield. We note that both phosphoroselenolate diesters (4a and $\mathbf{4 b}$ ) appeared stable towards both oxidation and hydrolysis by ${ }^{31} \mathrm{P}$ NMR during these manipulations and no degradation of $\mathbf{4 b}$ was observed upon storage in $\mathrm{D}_{2} \mathrm{O}$ for 12 hours under ambient conditions. More extensive investigations of the lability of internucleotide phosphoroselenolates are ongoing. 
Stec and co-workers had previously described the synthesis of $\mathbf{3 b}$ and both the chemical shifts and coupling constants $\left(\delta_{\mathrm{P}}=21.27\right.$ and $21.45 ;{ }^{1} J_{\mathrm{PSe}}=514$ and $\left.516 \mathrm{~Hz}\right)$ are consistent with our ${ }^{31} \mathrm{P}$ NMR data $\left(\delta_{\mathrm{P}}=20.43\right.$ and 20.31; ${ }^{1} J_{\mathrm{PSe}}=503$ and $\left.508 \mathrm{~Hz}\right)$. However, we noted a divergence in the reported data for the fully deprotected dinucleotide $\mathbf{4 b}$ in DMSO- $\mathrm{D}_{6}$ : reference 15 quotes $\delta_{\mathrm{P}}=19.87 ;{ }^{1} J_{\mathrm{PSe}}=700 \mathrm{~Hz}$ compared with $\delta_{\mathrm{P}}=5.11 ;{ }^{1} J_{\mathrm{PSe}}=337 \mathrm{~Hz}$ from the current investigation. Only a limited number of $O$,Se-dialkyl phosphoroselenolate diesters have been prepared but data both from a recent description of xylan-dissolving ionic liquids based upon the $O$,Se-dimethyl phosphate anion $\left(\delta_{\mathrm{P}}=9.2 ;{ }^{1} J_{\mathrm{PSe}}=336 \mathrm{~Hz}\right)^{28}$ and an earlier study of the relationship of the magnitude of the P-Se coupling constant and bond order ${ }^{29}$ supports our assignment.

In summary, we have demonstrated that the reactions of a nucleoside $H$-phosphonate diester with alkyl selenocyanates in the presence of a mild base and neutral silylating agent proceeded rapidly and cleanly to give the corresponding phosphoroselenolate triesters. By developing expeditious deprotection protocols, we have been able to isolate and provide, for the first time, full characterisation for an internucleoside phosphoroselenolate diester. Finally, Hackenburger has elegantly demonstrated the potential of bio-orthogonal "phosphorus click" reactions using azido-modified proteins ${ }^{30}$ and $\mathrm{P}(\mathrm{III})$-derivatised labelling agents and we note the potential to develop related chemistry based upon selenocyanate-modified biomolecules and suitable phosphites.

ACKNOWLEDGMENTS: This work was funded by the School of Chemistry and Chemical Engineering, QUB (PFC) and by the authors (OE, JSV). We acknowledge the technical services of Richard Murphy (NMR), Conor McCann (NMR and mass spectrometry) and Klaudia Bialek (mass spectrometry).

\section{REFERENCES AND NOTES}

1. $\quad$ Mudd, S. H.; Cantoni, G. L. Nature 1957, 180, 1052.

2. Wnuk, S. F. Tetrahedron 1993, 49, 9877-9936.

3. $\quad$ Sahu, P. K.; Kim, G.; Yu, J.; Ahn, J. Y.; Song, J.; Choi, Y.; Jin, X.; Kim, J.-H.; Lee, S. K.; Park, S.; Jeong, L. S. Org. Lett. 2014, 16, 5796-5799.

4. $\quad$ El-Shamy, I. E.; Abdel-Mohsen, A. M.; Alsheikh, A. A.; Fouda, M. M. G.; Ai-Deyab, S. S.; El-Hashash, M. A. Tetrahedron Lett. 2015, 56, 1183-1188.

5. $\quad$ Sheng, J.; Huang, Z. Chem. Biodivers. 2010, 7, 753-785.

6. $\quad$ Caton-Williams, J.; Huang, Z. Chem. Biodivers. 2008, 5, 396- 1872.

7. Hassan, A. E. A.; Sheng, J.; Zhang, W.; Huang, Z. J. Am. Chem. Soc. 2010, 132, 2120-2121.

8. $\quad$ Salon, J.; Jiang, J.; Sheng, J.; Gerlits, O. O.; Huang, Z. Nucleic Acids Res. 2008, 36, 7009-

7018.

9. $\quad$ Höbartner, C.; Micura, R. J. Am. Chem. Soc. 2004, 126, 1141-1149.

10. Morihiro, K.; Kodama, T.; Kentefu; Moai, Y.; Veedu, R. N.; Obika, S. Angew. Chem. Int. Ed. 2013, 52, 5074-5078.

11. Sahu, P. K.; Naik, S. D.; Yu, J.; Jeong, L. S. Eur. J. Org. Chem. 2015, 2015, 6115-6124.

12. Wilds, C. J.; Pattanayek, R.; Pan, C. L.; Wawrzak, Z.; Egli, M. J. Am. Chem. Soc. 2002, 124, 14910-14916.

13. Pallan, P. S.; Egli, M. Nat. Protoc. 2007, 2, 640-646.

14. Tram, K.; Wang, X.; Yan, H. Org. Lett. 2007, 9, 5103-5106.

15. Wozniak, L. A.; Sochacki, M.; Mitsuya, H.; Kageyama, S.; Stec, W. J. Bioorg. Med. Chem. Lett. 1994, 4, 1033-1036.

16. $\quad$ Sekine, M.; Hata, T. Chem. Lett. 1979, 801-802.

17. Tram, K.; Wang, X.; Yan, H. Org. Lett. 2007, 9, 5103-5106.

18. Toshimitsu, A. In Patai's Chemistry of Functional Groups -Organic Selenocyanates, Tellurocyanates and Related Compounds; John Wiley \& Sons, Ltd, Hoboken, New York, 2013. 19. Michalski, J.; Wieczorkowski, J. Rocz. Chem. 1959, 33, 105-118. 
20. Hua, G.; Woollins, D. In Best Synthetic Methods Organophosphorus (V) Chemistry Selenophosphorus Compounds; Timperley, C. M., Ed.; Academic Press, Oxford, 2015. pp 633-720.

21. Grieco, P. A.; Gilman, S.; Nishizawa, M. J. Org. Chem. 1976, 41, 1485-1486.

22. Lachkar, D.; Boudet, C.; Guinchard, X.; Crich, D. Can. J. Chem.- Rev. Can. Chim. 2012, 90, 944-953.

23. Vyle, J. S.; Williams, N. H.; Grasby, J. A. Tetrahedron Lett. 1998, 39, 7975-7978.

24. Eguaogie, O.; Conlon, P. F.; Ravalico, F.; Conway, L. P.; Lennon, M. E.; Hodgson, D. R. W.; Vyle, J. S. submitted.

25. Battaggia, S.; Smith, E. E.; Vyle, J. S. Nucleosides Nucleotides Nucleic Acids 2007, 26, 245254.

26. Hsiung, H.; Inouye, S.; West, J.; Sturm, B.; Inouye, M. Nucleic Acids Res. 1983, 11, 3227 3239.

27. Shimizu, M.; Wada, T.; Oka, N.; Saigo, K. J. Org. Chem. 2004, 69, 5261-5268.

28. Froschauer, C.; Hummel, M.; Laus, G.; Schottenberger, H.; Sixta, H.; Weber, H. K.; Zuckerstätter, G. Biomacromolecules 2012, 13, 1973-1980.

29. Glidewell, C.; Leslie, E. J. J. Chem. Soc., Dalton Trans. 1977, 527-531.

30. Hackenberger, C. P. R.; Schwarzer, D. Angew. Chem. Int. Edit. 2008, 47, 10030-10074

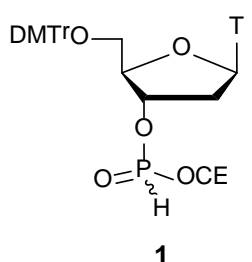

1 2a. 3a' $4 \mathbf{a}$

$$
\begin{aligned}
& \mathrm{ke}_{\mathrm{y}} \\
& \mathrm{R}=\widehat{\gamma}_{\mathrm{Ph}}
\end{aligned}
$$
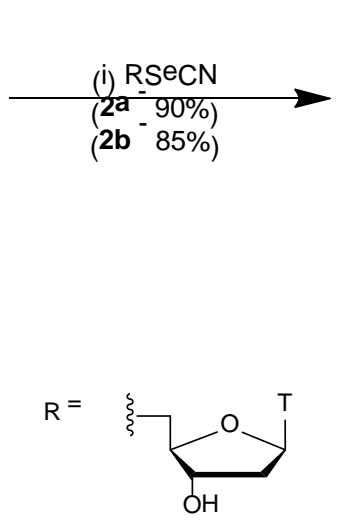

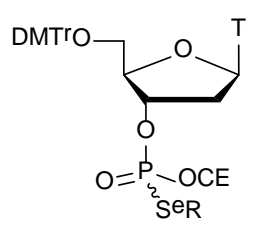

3a' b

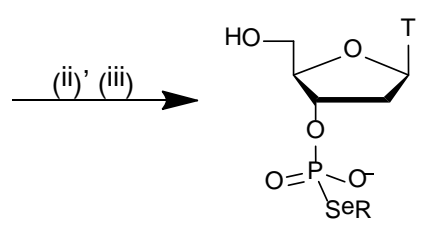

4a' b

2b' 3b' $4 b$

DMTr $=$<smiles>COc1ccc(C(C)(C)c2ccccc2)cc1</smiles><smiles>Cc1cn(C)c(=O)[nH]c1=O</smiles>

Scheme 1 Reagents and conditions. (i) BnSeCN (2a) or $\mathrm{dT}^{5} \mathrm{SeCN}$ (2b), N,Obis(trimethylsilyl)acetamide, 2,6-lutidine, $\mathrm{CHCl}_{3}$, rt, 60 min; (ii) $t \mathrm{BuNH}_{2}$, pyridine, rt, 30 min.; (iii) TFA, $\mathrm{Et}_{3} \mathrm{SiH}, \mathrm{CHCl}_{3}$, rt, 60 min (3a) or 90 min (3b).

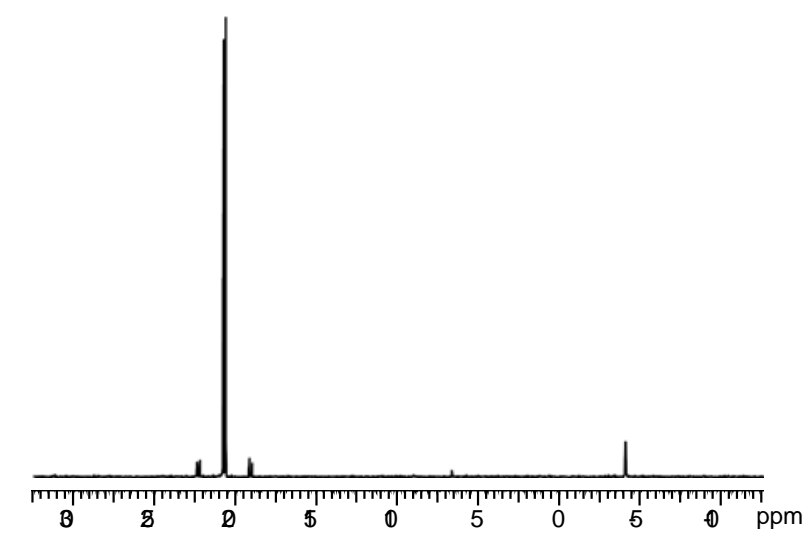

Figure $1{ }^{31} \mathrm{P}$ NMR spectrum of the crude reaction mixture of thymidine $H$-phosphonate (1) with benzylselenocyanate (2a) in the presence of BTMSA (2 equiv) and 2,6-lutidine (10 equiv) after 30 minutes. 